\title{
Universitätsprofessoren in (Mittel-)Europa vom Spätmittelalter bis zur Frühen Neuzeit (15.-18. Jahrhundert) / University Professors in (Central) Europe from the Late Middle Ages to the Early Modern Period (15th-18th Century)
} 10.-11. Juni 2019, Karlsuniversität, Karolinum, Prag

Profesoři středověkých a raněnovověkých univerzit byli v centru pozornosti konference, kterou uspořádal v Karolinu začátkem června letošního roku Historický ústav AV ČR spolu s Ústavem dějin Univerzity Karlovy za spolupráce Filosofického ústavu AV ČR. Setkání badatelů z šesti zemí se uskutečnilo v rámci grantu Universitas magistrorum. Profesoři pražské utrakvistické univerzity 1458-1622 (GAČR 18-00408S) jako jedna z aktivit Centra pro dějiny vzdělanosti. Bylo zaměřeno na kolektivy mistrů evropských univerzit, jejich společné identity, univerzitní, literární i mimoškolní činnost a na prosopografické výzkumy.

Jednání otevřeli zástupci pořádajících institucí. Úvodní přednášku držel prof. Joseph S. Freedman z Montgomery na téma literární činnosti mistrů artistických fakult v 16.17. století. Podal přehled kategorií literární produkce spojené s německými a rakouskými univerzitami (Tübingen, Dillingen, Salzburg, Ingolstadt aj.).

První sekce byla věnována prosopografickým studiím a jiným průzkumům kolektivního chování mistrů. K. Ożóg studoval první generaci mistrů v Krakově, z nichž velkou skupinu tvořili odchovanci z Prahy. Naopak polské profesory působící v Praze v širokém záběru 15.-18. století vyhledal R. Tomczak a nastínil jejich profily. Přesuny skupin mistrů mezi univerzitami byly časté. D. Luger představil italské profesory, kteří na univerzitě ve Vídni šírili humanistické myšlenky. Charakter univerzity v Altdorfu zkoumal W. Mährle. Jeho prosopograficky zaměřený referát hledal odpověd' na otázku ohledně příbuzenských vztahů v profesorském kolegiu. Př́mo pražské univerzity se týkaly dva referáty. M. Svatoš se zamýšlel nad terminologií označování vyučujících tituly mistrů nebo profesorů a následně sledoval problematiku vývoje těchto pojmů na př́kladu pražské školy. B. Zilynská představila osudy sedmi mistrů přelomu 50. a 60. let 15 . století, kteří tvořili katolickou opozici na pražské univerzitě. Jejich vypuzením byla završena utrakvizace univerzity, která se stala zemskou a konfesionálně vyhraněnou.

Druhá sekce byla zastřešena problematikou pamět'ové kultury. W. W. Schnabel analyzoval zápisy do památníků, a to zápisy mistrů univerzity v Altdorfu pro jejich kolegy a studenty, stejně jako zápisy do památníků samotných mistrů. Sledoval dobové trendy užitých sentencí, jazyka i doprovodné výzdoby. Jinou formou pamětové kultury jsou pohřební rituály a náhrobní kameny. Martin a Mlada Holí zpracovali tematiku pohřbů pražských mistrů z 15.-17. století. Hlavními místy jejich pohřbů byla Betlémská kaple a kaple Božího těla. Zajímavým pramenem pro životopisná data mistrů univerzity v Helmstedtu jsou pohřební biografie. J. L. Le Cam zkoumal, co všechno z nich lze načerpat, a předvedl to na př́ikladu prof. Christophera Schradera ze 17. století. 
Krátká třetí sekce byla věnována profesorským knihovnám. I. Hlaváček podal přehled zpráv o knihovnách kolejních i soukromých, které vlastnili univerzitní mistři, a to v širokém záběru středověku i raného novověku, od knihovních katalogů až po dochované kodexy i dobovou korespondenci o nich. J. Pešek se pak zaměřil na knihovnu jednoho významného profesora pražské školy, a sice Petra Kodicila z Tulechova, jehož knihovní sbírka je dokumentována soupisem v testamentárním inventárí. Jmenovité uvedení knih umožňuje poznat skladbu tohoto souboru.

V rámci čtvrté sekce byly představeny dva databázové projekty. Pražskou prosopografickou databázi, projektovanou pořadateli konference, prezentovala J. Synovcová Borovičková a J. Škudrnová, které jsou autorkami softwaru. Databáze zahrne mistry pražské univerzity, působící na škole v letech (1448)1458-1622 a umožní zpracovat několik studií na téma skladby a vývoje profesorského sboru pražské univerzity v jejím utrakvistickém období. Heidelberský projekt se týká dlouhého období od založení univerzity až do druhé poloviny 19. století. ${ }^{1}$ Ingo Runde seznámil př́tomné s historií zpř́istupňování univerzitních matrik (od edic přes jejich digitalizaci) až $\mathrm{k}$ jejich zpracování do databázového systému. Při zpracování digitalizátů byla využita rovněž tištěná edice matrik připravená v 19. století Gustavem Toepke.

Pátá sekce představila literární činnost tří pražských mistrů 16. a 17. století. M. Slavíková srovnávala dílo Matouše Kolína a Jáchyma Kameraria. M. Vaculínová se věnovala Janu Kampanovi a jeho žákům. Analyzovala odkazy na prameny v jejich dílech a zamýšlela se nad rolí takto užitých středověkých děl v novém dobovém kontextu. L. Storchová se zaměřila na Jana Matyáše ze Sudetu. Jeho nekonvenční chování ji inspirovalo k úvahám o významu univerzitních gradů a názorech na ně v dobových spisech. Matyášovi současníci nepolemizovali jen s jeho teoriemi o původu Slovanů. Poukazovali také na to, že jeho učenost není korunována univerzitním titulem.

Poslední sekce sledovala činnost mistrů mimo univerzitní prostředí. Pozornosti se dostalo diplomatickým úkolům pařížských profesorů (M. Hacke) stejně jako aktivitám na poli věroučných a politických dobrozdání heidelberských profesorů, kteří byli dlouhodobě angažováni $\mathrm{v}$ učených polemikách a inkviziční praxi zaměřené proti českým viklefistům a husitům (H. Hawicks). Jiným polem mimoškolní působnosti univerzitních mistrů bylo městské prostředí (M. Durčanský o kariérách mistrů v českých městech a jejich působení i dohlídce na městské školy), nebo zapojení do struktur protestantské církve. K. D. Beims využil ke svému referátu knihu životopisů soudobých učenců od Melchiora Adama (přelom 16. a 17. století) a na několika př́kladech předvedl vzorové kariéry luteránských superintendentů, ale i úspěšné angažmá učených právníků na panovnických dvorech.

Konferenční jednání shrnul v závěrečném vystoupení J. Pešek. Konstatoval, že univerzitní historiografie přesouvá svůj zájem od událostních výkladů a institucionálních popisů k jiným úhlům pohledu, čehož dokladem byla i prítomná konference. Pozornost se obrací více ke kulturním dějinám a osobnostním profilům. Profesoři jsou vnímáni jako duchovní elita, která vedle vlastní učitelské činnosti má svoji roli v dalších oblastech života společnosti. Dosavadní primární zdroje informací (rukopisné a tištěné prameny a jejich kritické edice) jsou přitom čím dál tím častěji doplňovány také digitalizovanými dokumenty a databázemi.

1 <https://www.ub.uni-heidelberg.de/helios/digi/unihdmatrikel.html> (ověřeno 4. 9. 2019). 
Dodejme, že dvě třetiny z 21 referentů se zamýšlely nad tématy raného novověku, což je v př́ípadě pražské univerzity pozitivní jev, protože zde zůstávají větší rezervy v neprobádaných oblastech. Na druhé straně je ale třeba mít na mysli, že tematická skladba referátů byla ovlivněna předem ohlášenou profilací konference, obsah tedy neodráží jen aktuální badatelské trendy.

Blanka Zilynská - Marek Ďurčanský doi: $10.14712 / 23365730.2019 .22$ 